\title{
Preliminary Survey of Composition, Generation and Management of Solid Wastes in Ward 7, Soc Trang City, Soc Trang, Vietnam
}

\author{
Nguyen Thanh Giao
}

College of Environment and Natural Resources, Can Tho University, Vietnam

\begin{abstract}
This research was to investigate the current status of solid waste generation, composition and management in Ward 7, Soc Trang City, Soc Trang Province through interviewing the households of understandings and practices with solid wastes and the placing the plastic bags for collecting the generated wastes directly at the households for compositional analysis. The results showed that organic matter accounted for $62.31 \%$, recyclable and reusable items such as plastic accounted for $19.61 \%$, paper occupied $14.55 \%$, glass took $1.16 \%$, accounted for $0.79 \%$, cloth occupied $1.69 \%$ and foam took $0.74 \%$. Hazardous waste only accounted for a small proportion $(0.11 \%)$. The average rate of solid waste generation was $0.91 \mathrm{~kg} / \mathrm{household/day} \mathrm{and} \mathrm{the} \mathrm{average} \mathrm{waste} \mathrm{generation} \mathrm{rate} \mathrm{per} \mathrm{person} \mathrm{was} 0.22$ $\mathrm{kg} /$ person/day. Currently, the management, collection and transportation of domestic solid wastes in the ward 7 has not been guaranteed, not yet effective, causing several environmental problems; open dumping is still commonly seen in the study area due to lack of sanitary landfills. Local authority should take proper measures to effectively manage solid wastes in Ward 7, Soc Trang City, Soc Trang province.
\end{abstract}

Keywords-domestic wastes, waste collection, sorting system, generation rate, Soc Trang.

\section{INTRODUCTION}

The natural area of Soc Trang province is $160,058.69$ hectares, accounting for about $4 \%$ of the Mekong Delta area and about $0.4 \%$ of the country's total natural area. Soc Trang province comprise of eight administrative units including 1 city, 2 towns and 5 districts. As of April 1, 2019, Soc Trang province's population reached 733,017 people, population density reached 480 people $/ \mathrm{km}^{2}$. In particular, the urban population reaches nearly 186,371 people, accounting for $25.4 \%$ of the provincial population, the rural population reaches 546,646 people, accounting for $74.6 \%$ of the population. Economic growth rate (GRDP) reached $6.5 \%$, of which agriculture forestry - fishery (region I): $2.77 \%$, industry - construction (region II): $10.19 \%$, trade - service area (region III): $6.51 \%$. GRDP per capita is VND 45 million/person/year, equivalent to USD 1,945, up $15.63 \%$ over the same period (Soc Trang People's Committee, 2019). Soc Tran province is entering the period of industrialization - modernization of the country and the development society in order to meet the needs and interests of the people, while also leading to difficult problems such as environmental pollution is increasing. The amount of waste generated from daily activities as well as production activities of people is increasing, and the level of environmental pollution is increasingly serious in many different regions. In 2015, the whole province of Soc Trang had a solid waste generation of nearly 350 tons/day. In particular, nonhazardous solid waste was about 312.34 tons/day, hazardous solid waste was approximate 37.28 tons/day. It is expected that the amount of generated solid waste will continue to increase by 741 tons/day by 2025 (Soc Trang People's Committee, 2019). Currently, solid waste classification in the province has not been implemented at source, the collection rate is not high, in some places the collection only reaches $45 \%$. The main treatment technology is landfill, while the landfills are overloaded, unhygienic, there is no form of leachate treatment. Previous research showed that leachate from the landfill contained heavy metals (Toufexi et al., 2013). The concentration of heavy metals in leachate depends on the composition of the waste. Heavy metals are considered hazardous waste because they can enter the food chain and increase levels in the organism. Heavy metals present in the environment around the landfill are a major threat to human and biological health because they are durable, non- 
biodegradable, can disperse and accumulate in the ecosystem, plants and animals, and finally to humans through consumption (Klinsawathom et al., 2017). To solve the problem of domestic waste, it is necessary to have a synchronous solution to limit the generation, classification at source, collection, transportation, disposal, science and technology and finance. The study was conducted to preliminarily investigate the composition and rate of generation of pilot solid waste in Ward 7 of Soc Trang City. The study also investigated people's knowledge about solid waste in the study area. The research results provide important information for solid waste management in ward 7 , Soc Trang city.

\section{MATERIALS AND METHODS}

Information on the current situation of generation, collection, transportation and solid waste management in Ward 7, Soc Trang city was collected by interview the households. The questionnaire content included general information about the interviewee such as gender, age, education level, occupation; information on current situation, source separation, collection time, impacts of solid waste on environment and health, assessment of current status of solid waste management in the study area. To assess the rate of generation and composition of solid waste, thirty households in the surveyed area were selected for providing plastic bags to store all solid waste in the family. Each day the placed plastic bags were collected at 5:00 PM to classify and calculate solid waste composition and rate of generation of solid wastes. Waste separation was conducted in accordance with the guidance of the Department of Natural Resources and Environment of Ho Chi Minh City. Specifically, organic waste includes easily biodegradable waste including uneaten food, vegetables, tubers, fruits, leaves, twigs and recalcitrant including nylon bags, straws, bottles, glasses, plastic jars; inorganic wastes includes glass, bottles and jars; toxic wastes includes battery, light bulb, rubber, empty pesticide bottles; and other waste includes soil, stone, rubble. The interview data were imported into Excel spreadsheets (Microsoft Excel 2016, Microsoft, USA) to aggregate, calculate percentages and present data in the form of simple tables and charts.

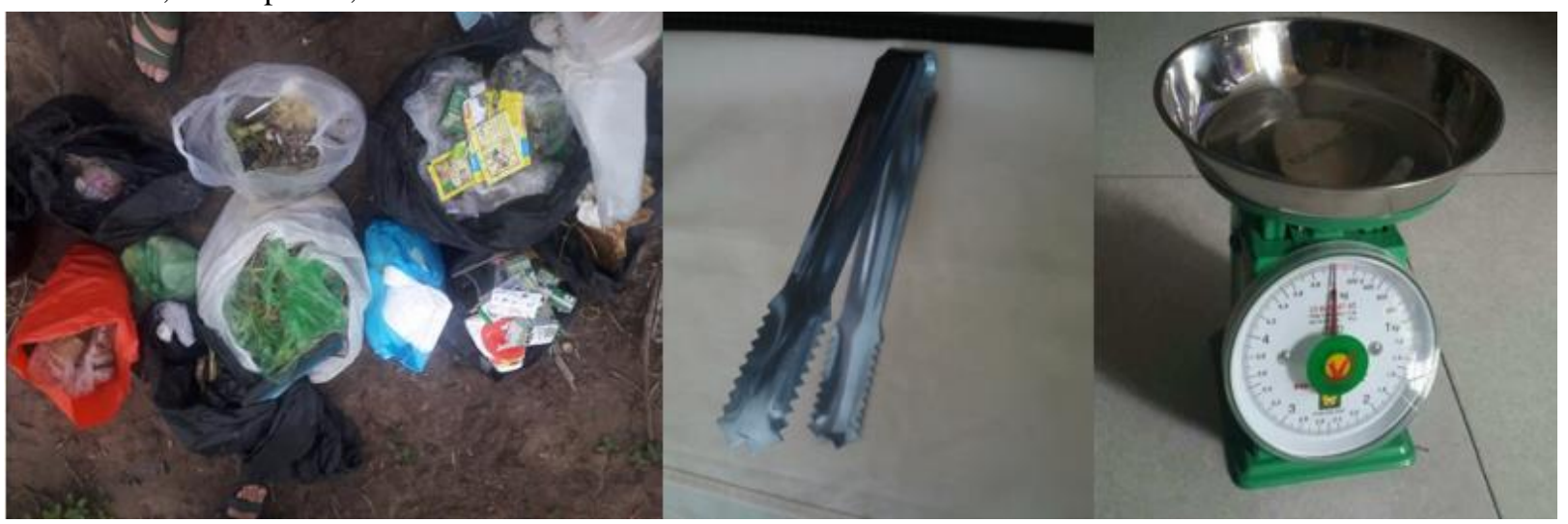

Fig.1: Collected solid wastes from the households

\section{RESULTS AND DISCUSSION}

\subsection{General information of the respondents}

Males were accounted for $73.3 \%$ while females occupied $26.7 \%$. In the surveyed area, Kinh ethnic group was $73 \%$, Chinese ethnic group was $7 \%$ and the Khmer ethnic group was $20 \%$.Educational level of the households was relatively diverse. The interviewees with university, college, high school, secondary school, primary school, and illiteracy accounted for 10\%, 23\%, 44\%, 13\%, $7 \%$ and $3 \%$, respectively (Figure 2 ). The education level of the interviewees is an essential issue in the people's understanding of the environment. It can be concluded that the educational level of the people in Ward 7 in Soc Trang City is mostly moderately-educated. 


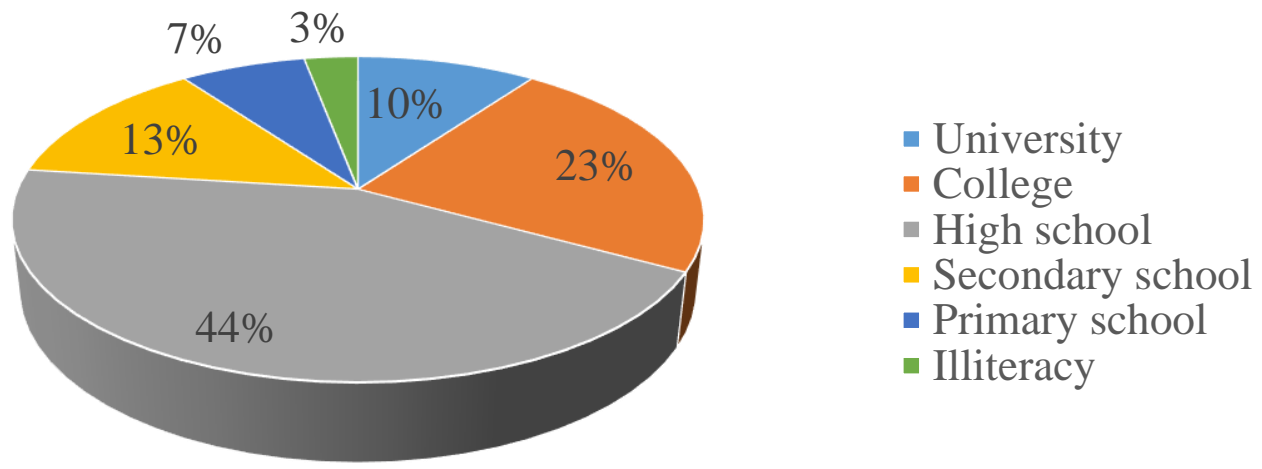

Fig.2: Educational levels in the study area

The dominant occupation in the research area was trading (accounting for 43\%), government officials (accounting for $7 \%$ ); housewives (accounting for $7 \%$ ); workers (accounting for $20 \%$ ); agricultural workers (7\%), tailors $(10 \%)$, drivers $(3 \%)$, and construction workers $(3 \%)$ (Figure 3). Occupation is one of the factors affecting the generation rate of domestic waste. In fact, the traders are also housewives in the family, along with home tailors, as they are known to stay at home so they have a big role in discharging wastes. Because they have the ability to go to the market, cook, but the business also

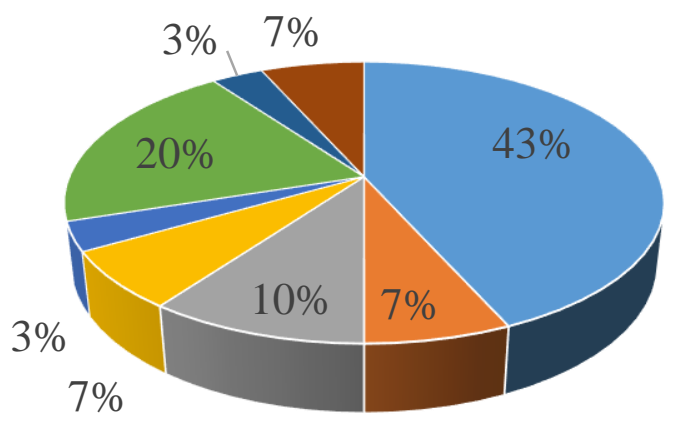

indirectly discharges the waste into the environment such as packaging, nylon bags. The majority of people with high education would have a stable job and have a long time during the day at work so there would be less waste generation in the households. However, high-income people tend to produce more wastes due to their greater consumption capacity. In summary, occupation and education level are important factors affecting public awareness in environmental protection, especially waste management.
- Small business

- Government officials

- Tailor

- Agricultural workers

- Drivers

- Workers

- Construction workers

Fig.3: Occupation of the interviewed households

\subsection{Current status of solid waste generation}

Survey results showed that the percentage of households generating solid waste $0-0.5 \mathrm{~kg}$ accounted for $7 \%$, from $0.5-1 \mathrm{~kg}$ accounted for $33 \%, 1-2 \mathrm{~kg}$ accounted for
$40 \%$ and over $2 \mathrm{~kg}$ accounted for $20 \%$. Solid waste in ward 7 , mainly generated from specific sources such as from households, business and production establishments (Figure 4). 


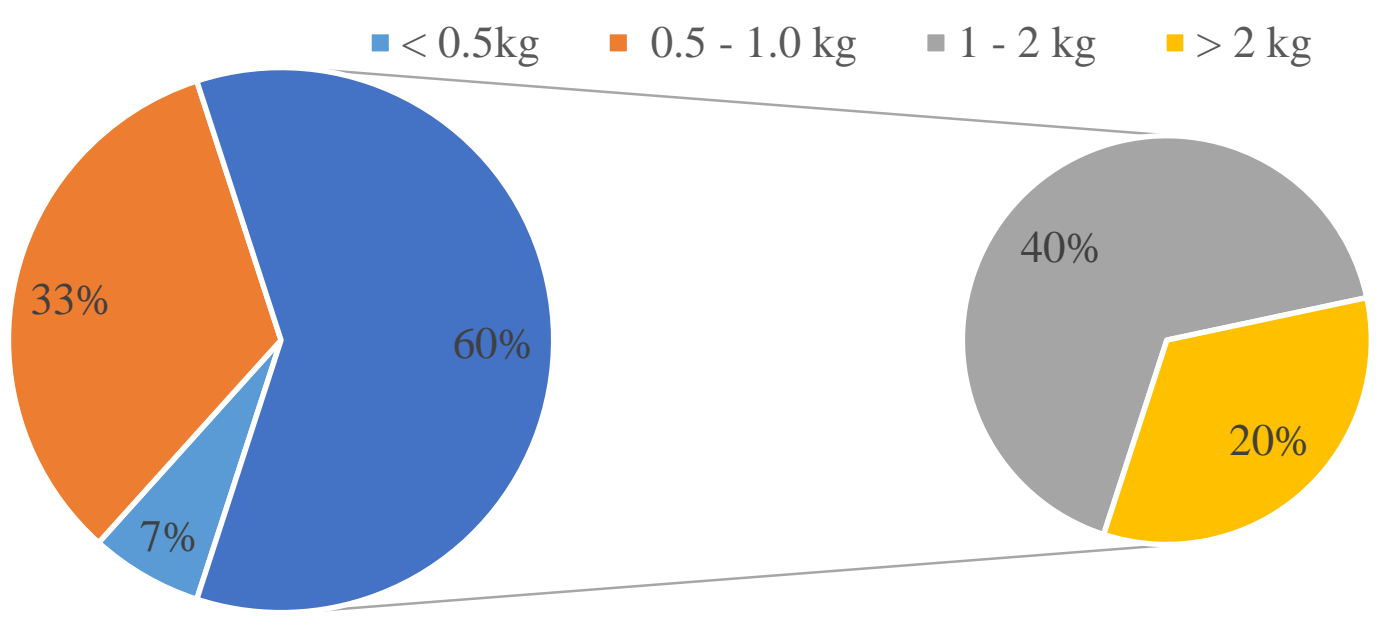

Fig.4: Waste generation in the study area

Through interviewing and observing waste before being collected, it showed that the amount of waste from production and business establishments has the largest volume because it is the area where many types of products are traded.Table 1 showed that in Ward 7 of Soc Trang city, the highest amount of waste per capita was 0.46 $\mathrm{kg} /$ person/day and the lowest was $0.13 \mathrm{~kg} /$ person/day. The amount of waste generated by each household varied widely by occupation, income level, and living and production habits of households. However, this difference is mainly due to the level of income, which results in higher living standards, eating and drinking, and household activities generating more solid wastes. On average, each household in Ward 7 discharged about 0.91 $\mathrm{kg} /$ household/day or $0.22 \mathrm{~kg} / \mathrm{person} / \mathrm{day}$. Thus, the average volume of solid waste per capita of the households in the sampling area was relatively low with $0.22 \mathrm{~kg} / \mathrm{person} / \mathrm{day}$ (Table 1). Numbers of households in the survey should be increased to get more representative result.

Table1. Solid waste generation at ward 7 of Soc Trang province

\begin{tabular}{lllccc}
\hline No. & $\begin{array}{l}\text { Household } \\
\text { code }\end{array}$ & $\begin{array}{l}\text { No. of family } \\
\text { members }\end{array}$ & $\begin{array}{c}\text { Total weight } \\
\text { (kg/week) }\end{array}$ & $\begin{array}{c}\text { Amount of solid waste } \\
\text { per household } \\
(\mathrm{kg} / \mathrm{hh} / \mathrm{day})\end{array}$ & $\begin{array}{c}\text { Amount of solid waste } \\
\text { per capita } \\
\text { (kg/person/day) }\end{array}$ \\
\hline 1 & HH1 & 5 & 10.92 & 1.56 & 0.31 \\
2 & HH2 & 3 & 9.73 & 1.39 & 0.46 \\
3 & HH3 & 5 & 4.94 & 0.71 & 0.14 \\
4 & HH4 & 5 & 5.61 & 0.80 & 0.16 \\
5 & HH5 & 4 & 4.93 & 0.70 & 0.18 \\
6 & HH6 & 4 & 3.81 & 0.54 & 0.14 \\
7 & HH7 & 4 & 6.43 & 0.92 & 0.23 \\
8 & HH8 & 4 & 7.02 & 1.00 & 0.25 \\
9 & HH9 & 5 & 4.89 & 0.70 & 0.13 \\
10 & HH10 & 3 & 5.63 & 0.80 & 0.27 \\
11 & HH11 & 5 & 4.93 & 0.70 & 0.14 \\
12 & HH12 & 6 & 5.85 & 0.84 & 0.14 \\
13 & HH13 & 4 & 8.89 & 1.27 & 0.32 \\
14 & HH14 & 4 & 5.62 & 0.80 & 0.20
\end{tabular}




\begin{tabular}{lllllll}
15 & HH15 & 5 & 6.56 & 0.94 & 0.19 & 0.22 \\
\hline Mean & 4.4 & 6.384 & 0.91 & 0.22 \\
\hline
\end{tabular}

\subsection{Solid waste composition}

From the results of the study, the composition of solid waste in the area is mainly organic matter, paper, plastic, glass, metal, cloth, foam and hazardous waste. Among the components on the biodegradable organic waste accounted for $62.31 \%$ including mostly vegetables, tubers, fruits, leaves, tree branches. This component is easy to decompose under high temperature conditions and within an appropriate time, this amount of waste will decompose and create gases, especially $\mathrm{H}_{2} \mathrm{~S}$ and $\mathrm{CH}_{4}$ gas, causing odors to pollute the environments. In the area, this is also a disadvantage for waste collection and treatment because if it is not collected in time, the easily decomposable organic waste can cause stench and develop bacteria to pollute the environments affecting people's lives and health. In addition, degraded organic waste attracts, arises and develops mice, flies, mosquitoes, cockroaches and other germs that cause many infectious diseases to humans and domestic animals.

Plastic was the second main component

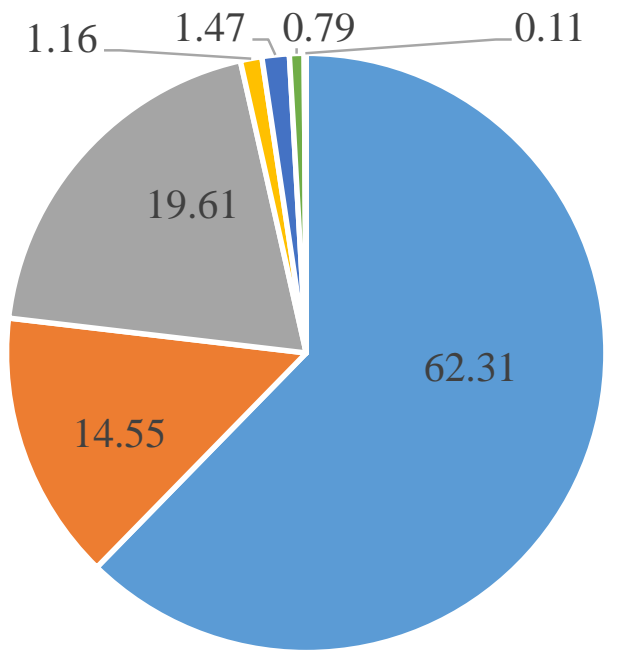

- Organic wastes

- Paper

- Plastic

Glass

- Cotton fabric

- Heavy metals

- Hazardous waste

Fig.5: Composition of solid wastes in the study area

From comparative data, it can be seen that domestic wastes in the study area in Can Tho and in the study area in Soc Trang has relatively diverse components. Solid waste is generated mainly from business areas. Main components were organic matter, paper, plastic, glass, and hazardous wastes. The proportion of each type of solid waste generation in the two study areas was different. In the study area in Can Tho, there was a higher content of organic matter $(72.66 \%)$ than Soc Trang (62.31\%). The composition of other wastes surveyed in Can Tho which were higher than those in Soc Trang were glass $(2.65 \%)$ and hazardous waste $(1.39 \%)$. Paper and plastic in Soc Trang accounted for a higher proportion than those in Can Tho. 
International Journal of Environment, Agriculture and Biotechnology, 5(4)

Jul-Aug, 2020 / Available: https://ijeab.com/

Table2.Composition of solid wastes in Soc Trang and Can Tho city

\begin{tabular}{clcc}
\hline No. & Composition & Ward 7, Soc Trang (\%) & Cai Khe, Can Tho (\%) \\
\hline 1 & Organic matter & 62.31 & 72.658 \\
2 & Paper & 14.55 & 7.242 \\
3 & Plastic & 19.61 & 13.404 \\
4 & Glass & 1.16 & 2.653 \\
5 & Hazardous wastes & 0.11 & 1.392 \\
\hline 6 & Reference & This study & Previous study \\
\hline
\end{tabular}

\subsection{Understanding of solid wastes of the households}

The survey results showed that people often found out information about the environment from the mass media (30\%), local governments (26\%), local governments combined with mass media (20\%), relatives and neighbors $(10 \%)$ and relatives and neighbors combined with local authorities (7\%). Through interviewing 30 households about the impact of solid wastes on health, $90 \%$ of interviewed people said that waste affects health, $10 \%$ said it does not affect. In $90 \%$ of households who were aware of the impact of solid waste, they believed that solid waste would cause digestive diseases $(60 \%)$, respiratory $(27 \%)$, skin diseases (13\%). However, the remaining $10 \%$ said that it was not affected because they did not understand the impact of waste and the access to propaganda, possibly because of low awareness due to low education.

\subsection{Management of solid wastes in the households}

The interviewing results on the status of household waste classification indicated that $72 \%$ of the households had their waste classified at home, and the remaining $28 \%$ of the households said that the solid waste was not classified. This proved that the majority of households classifiedsolid waste daily in the ways that they only pick the paper, scrap metal, and plastic bottles which can be sold to vendors. As for nylon bags, people keep them for the reuse. Part of the leftovers would be reused as pet food. This classification could also help to reduce the amount of solid waste collected thus reducing environmental pollution and this habit should be encouraged extensively. However, $28 \%$ of respondents said that environmental management belongs to government officials. In reality, the households do not know how to classify solid wastes. They just take out the valuable items for future use or for money. Solide waste was collected at a fixed daily time (13:00 PM) with the frequency of 1 time/day. All respondents did not have any feedback on the waste collection scheme. $100 \%$ solid wastes of households were collected. Each household pays a monthly waste collection fee of VND 15,000 and 100\% of households think it is reasonable. People agree to pay an additional collection fee to improve the environment related to domestic solid waste.

\subsection{Current solid waste management of the local authority}

Currently, in Soc Trang city, Soc Trang Urban Construction Joint Stock Company is the only unit collecting and treating domestic solid waste. Solid waste collection facilities include specialized vehicles, trucks and trolleys to collect domestic solid waste from households, facilities, public areas to transfer points, then solid waste will be transported to a garbage compactor (with a spray to treat odors and flies) and transported to Soc Trang solid waste treatment plant for disposal by burial method. According to the interviews with officials of Ward 7 of Soc Trang City, the garbage collection activities in the ward reached about $80 \%$ of the amount of generated solid waste. Although the collection of domestic solid wastes in the ward is focused on implementation. However, due to the low awareness of certain households, they do not collect waste but throw it away in public areas, causing loss of urban beauty and environmental pollution. In addition, some households near the countryside and garbage collection facilities have not been able to collect waste yet, so the people themselves collect and treat but not thoroughly, so the wastes are generated immediately roadside, along canals and ditches. 


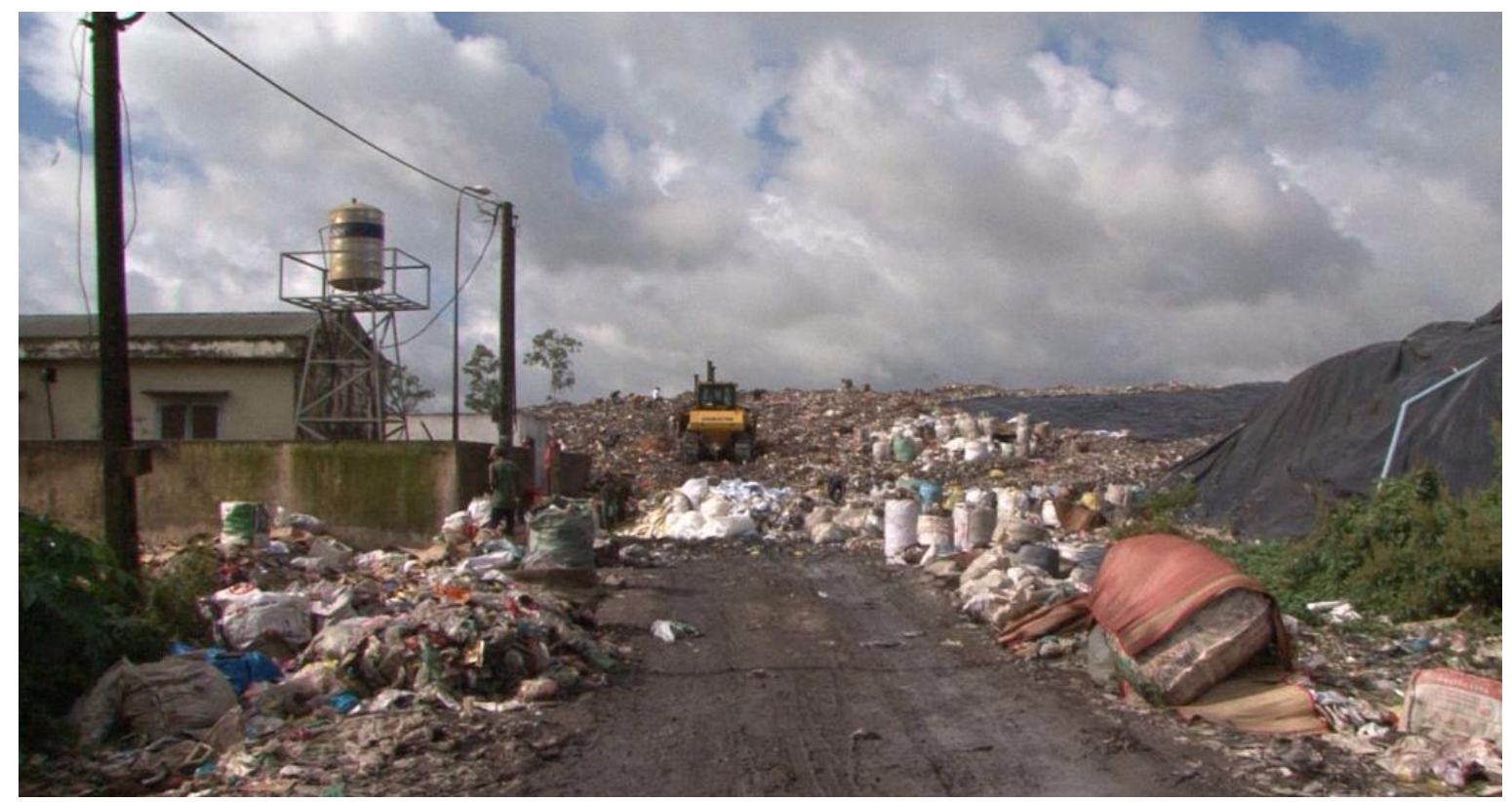

Fig.6: Open dumping in the study area

Local environmental protection has been focused. At present, Ward 7 Committee has assigned a task for an officers in charge of Land Administration - Environment to perform the role of advising and reporting on environmental protection in the locality, updating legal documents. In the past year, the locality has created favorable conditions for the officials to participate in training courses on environmental protection organized by the Department of Natural Resources and Environment of Soc Trang city. Environmental officers are allowed to implement legal documents such as the current Law on Environmental Protection; Decree No. 18/2015/ND-CP dated February 14, 2015 of the Government; Circular No. 27/2015/TT-BTNMT dated May 29, 2015 of the Ministry of Natural Resources and Environment. At the same time, the ward People's Committee also applies the legal policies on the sanctioning of administrative violations in the field of environmental protection such as: Decree 38/2015/ND$\mathrm{CP}$ on waste and discarded material management; Decree 59/2007/ND-CP on solid substance management; Decree 155/2016/ND-CP stipulates penalties for administrative violations against regulations on environmental protection. The ward People's Committee draws up a plan for environmental protection, performs the task of protecting the environment and preserving environmental sanitation in the locality; regularly propagandize and mobilize people to develop environmental protection content, guide the inclusion of criteria for environmental protection in assessing residential areas and cultural families. However, environmental management in the locality still faces many difficulties, largely due to poor people's sense of common sanitation, and the domestic waste of some households who do not dispose of their garbage in accordance with regulations leading to environmental issues.

\subsection{Recommended solutions for solid waste management}

In order to overcome difficulties and exist in environmental protection in the area, in the coming time, the People's Committee of Ward 7 should implement the following solutions:

Disseminating information about newly promulgated environmental regulations, framework for sanctioning violations of environmental protection to community through meetings with the community. Using the mass media to bring educational message to the people. The use of banners and posters to show fully and briefly the contents to be propagated. Continuing to launch the movement of garbage collection and street sanitation on the occasion of World Water Day (March 22), World Environment Day (June 5), Vietnam Sea and Islands Week, the campaign to make the world cleaner, ... Local officials actively guide households in remote areas to collect and treat waste such as burial in home gardens or burning, not disposing of solid waste to canals. Launching hazardous waste collection (pesticides after use) to clean the environment. Launching the emulation movement for environmental protection in Soc Trang city according to the Plan No. 10/KH-UBND dated January 11, 2018 of the People's Committee of Soc Trang City.

Strengthening the inspection and monitoring of operations of livestock farms, thereby detecting and strictly handling violations, as well as detecting establishments 
causing environmental pollution. Managing and closely monitoring the exploitation of underground water, enterprises operating in exploiting underground water in the ward area. Promoting the investment in socialization of environmental protection in the ward, attracting capital from businesses and people to build gathering points, handle agricultural wastes. Dredging canals and ditches have been deposited, cleared the flow to meet the circulation needs and agricultural production of people. Sending environmental officials to participate in training courses organized by departments to improve their professional knowledge and skills. Requiring environmental officials to regularly update environmental laws and disseminate to groups, hamlets and households in the ward area.

\section{CONCLUSION}

According to the survey results, the amount of solid waste generated by households generated an average of $0.91 \mathrm{~kg} /$ household/day and the average amount of waste generated by each person was $0.22 \mathrm{~kg} /$ person/day. The composition of household waste was relatively abundant, the composition of organic substances in the garbage $(62.31 \%)$ was higher than the other components, followed by the components that can be recycled and reused such as plastic $(19.61 \%)$, paper $(14.55 \%)$, glass $(1.16 \%)$, metal $(0.79 \%)$, cloth $(1.69 \%)$, styrofoam $(0.74 \%)$, and hazardous wastes $(0.11 \%)$. Most people do not know how to separate waste at source. The means of garbage collection and transportation were still simple and seriously degraded. Currently, the management, collection and transportation of domestic waste in ward 7 has not been guaranteed, not yet effective, causing many problems. The locality needs to invest more specialized collection vehicles, improve equipment, regularly supervise the collection, transportation and handling to achieve higher efficiency. Encouraging people to separate and reuse biodegradable organic matters for composting and biogas. Public waste bins are needed to limit the current littering. Local environmental managers need to strengthen the inspection, examination and supervision of the objects engaged in production and business activities that cause environmental pollution.

\section{REFERENCES}

[1] Nguyen Van Phuoc (2008), Management and treatment of solid waste: volume 2. Hanoi Construction Publishing House, 2008.

[2] Soc Trang People's Comittee (2009). Soc Trang Province Environmental Status Report 2009.
[3] Mai Vang Ngoc Bich (2018). Current status of solid waste management in Cai Khedistric, Can Tho city. Bachelor's thesis. Can Tho University.

[4] Klinsawathom, T., Songsakunrungrueng, B., and Pattanamahakul, P., 2017. Heavy metal concentration and risk assessment of soil and rice in and around an open dumpsite in Thai Lan. Enviromentasia, 10(2), 53-64.

[5] Toufexi, E., Tsarpali, V., Efthimiou, I., Vidali, M.S., Vlastos, D., Dailianis, S., 2013. Environmental and human risk assessment of landfill leachate: an integrated approach with the use of cytotoxic and genotoxic stress indices in mussel and human cells. Journal of Hazardous Materials 2013; 260: 593-601.

[6] Hang, X., Wang, H., Zhou, J., Ma, C., Du, C., and Chen, X., 2009. Risk assessment of potentially toxic element pollution in soil and rice (Oryza sativa) in a typical area of the Yangtze River delta. Environmental Pollution. 157 (8-9): 2542-49.

[7] Lakhdar, A., Scelza, R., Scotti, R., Rao, M.A., Jedidi, N., Gianfreda, L., Abdelly, C. 2010. The effect of compost and sewage sludge on soil biologic activities in salt affected soil. Revista de la ciencia del sueloy nutrición vegetal 10, 40-47. 